\title{
An improved Antarctic dataset for high resolution numerical ice sheet models (ALBMAP v1)
}

\author{
A. M. Le Brocq ${ }^{1,2}$, A. J. Payne ${ }^{3}$, and A. Vieli ${ }^{1}$ \\ ${ }^{1}$ Department of Geography, Durham University, Durham, UK \\ ${ }^{2}$ Geography, College of Life and Environmental Sciences, University of Exeter, Exeter, UK \\ ${ }^{3}$ Bristol Glaciology Centre, School of Geographical Sciences, University of Bristol, Bristol, UK
}

Received: 14 June 2010 - Published in Earth Syst. Sci. Data Discuss.: 28 June 2010

Revised: 1 October 2010 - Accepted: 5 October 2010 - Published: 11 October 2010

\begin{abstract}
The dataset described in this paper (ALBMAP) has been created for the purposes of high-resolution numerical ice sheet modelling of the Antarctic Ice Sheet. It brings together data on the ice sheet configuration (e.g. ice surface and ice thickness) and boundary conditions, such as the surface air temperature, accumulation and geothermal heat flux. The ice thickness and basal topography is based on the BEDMAP dataset (Lythe et al., 2001), however, there are a number of inconsistencies within BEDMAP and, since its release, more data has become available. The dataset described here addresses these inconsistencies, including some novel interpolation schemes for sub ice-shelf cavities, and incorporates some major new datasets. The inclusion of new datasets is not exhaustive, this considerable task is left for the next release of BEDMAP, however, the data and procedure documented here provides another step forward and demonstrates the issues that need addressing in a continental scale dataset useful for high resolution ice sheet modelling. The dataset provides an initial condition that is as close as possible to present-day ice sheet configuration, aiding modelling of the response of the Antarctic Ice Sheet to various forcings, which are, at present, not fully understood.
\end{abstract}

\section{Introduction}

There is a great deal of uncertainty over the potential contribution of the Antarctic Ice Sheet to sea level rise over the next century. The 2007 IPCC (Intergovernmental Panel on Climate Change) report (see chapter 10: Meehl et al., 2007), for example, did not include the potential contribution to sea level change from retreat of the Antarctic Ice Sheet because of the uncertainty over its response to climate change. In order to reduce this uncertainty, high-resolution numerical ice sheet models (grid resolution of $\leq 5 \mathrm{~km}$ compared to $20-50 \mathrm{~km}$ previously), with higher-order physics, are needed to reproduce the present day behaviour of the ice sheet and predict the response of the ice sheet into the future. Advances are currently being made in developing highresolution, higher-order models (e.g. Pattyn, 2002; Price et al., 2007; Hubbard et al., 2009). There is also particular focus on representing grounding line (where the ice changes from being grounded to floating) retreat/advance (e.g. Schoof,

Correspondence to: A. M. Le Brocq (a.lebrocq@exeter.ac.uk)
2007; Pollard and DeConto, 2009). However, the results from these models are only as good as the data that are input; in particular the elevation of the bed and bathymetry at the grounding line.

It is now possible to download a community ice sheet model (e.g. Elmer/Ice, Glimmer-CISM, SICOPOLIS), making ice sheet modelling accessible for many purposes, however, without adequate data it is difficult to utilise such models. Whilst the BEDMAP dataset (Lythe et al., 2001) was a step forward when it was created, providing data on ice thickness, surface and bed elevations, there are a number of inconsistencies within the dataset (see Sect. 3). These inconsistencies cause difficulties for ice sheet models, particularly those which use the present day configuration as a starting point. Also since the release of BEDMAP, more data have become available regarding both the ice thickness and surface elevation.

This paper presents an improved version of the BEDMAP dataset for the purpose of high resolution ice sheet modelling, addressing the inconsistencies which make BEDMAP unsuitable for this purpose. The dataset described here incorporates some major new datasets (e.g. AGASEA/BBAS ice thickness, Nitsche et al. (2007) bathymetry), but by no 
Table 1. List of datasets included and source.

\begin{tabular}{|c|c|c|c|c|c|}
\hline Grid & Section & Description & Units & Data Source/Provider & References \\
\hline mask & 2.1 & $\begin{array}{l}\text { Basic mask, ocean/ice } \\
\text { shelf/grounded ice }\end{array}$ & - & MOA grounding line & $\begin{array}{l}\text { Haran et al., 2005; } \\
\text { Scambos et al., } 2007\end{array}$ \\
\hline mask+ & 2.2 & Ice free/ice stream mask & - & $\begin{array}{l}\text { ADD, Jonathan Bamber, } \\
\text { Laura Edwards }\end{array}$ & www.add.scar.org \\
\hline glmask & 2.3 & Grounding line uncertainty mask & - & Anne Le Brocq & This document \\
\hline umask & 3.6 & $\begin{array}{l}\text { Mask indicating areas where surface is not } \\
\text { consistent with JLB/JAG DEM }\end{array}$ & - & Anne Le Brocq & This document \\
\hline bmask & 3.6 & $\begin{array}{l}\text { Mask indicating sources of } \\
\text { bed/bathymetry data }\end{array}$ & - & Anne Le Brocq & This document \\
\hline usrf & 3.2 & Upper ice surface elevation & $\mathrm{m}$ & $\begin{array}{l}\text { Jennifer Griggs/ } \\
\text { Jonathan Bamber, RAMP }\end{array}$ & Bamber et al., 2009; Liu et al., 1999 \\
\hline lsrf & 3.1 .2 & Lower ice surface elevation & $\mathrm{m}$ & $\begin{array}{l}\text { Jennifer Griggs/ } \\
\text { Jonathan Bamber, BEDMAP, } \\
\text { AGASEA/BBAS }\end{array}$ & $\begin{array}{l}\text { Griggs and Bamber, 2009b; } \\
\text { Lythe et al., 2001; Vaughan et al., 2006; } \\
\text { Holt et al., } 2006 .\end{array}$ \\
\hline topg & $3.3,3.4$ and 3.5 & Bed/bathymetry elevation & $\mathrm{m}$ & BEDMAP, Frank Nitsche & Lythe et al., 2001; Nitsche et al., 2007 \\
\hline lsrf2 & 3.1 .2 & $\begin{array}{l}\text { Lower ice surface elevation } \\
\text { (including Recovery basin modification) }\end{array}$ & $\mathrm{m}$ & As lsrf, plus Anne Le Brocq & As lsrf, plus Le Brocq et al., 2008 \\
\hline topg2 & $3.3,3.4$ and 3.5 & $\begin{array}{l}\text { Bed/bathymetry elevation } \\
\text { (including Recovery basin modification) }\end{array}$ & $\mathrm{m}$ & As topg, plus Anne Le Brocq & As topg, plus Le Brocq et al., 2008 \\
\hline firn & 3.1 .2 & Firn correction & $\mathrm{m}$ & Michiel van den Broeke & Van den Broeke et al., 2008 \\
\hline temp & 4 & Surface air temperature & ${ }^{\circ} \mathrm{C}$ & Josefino Comiso & Comiso, 2000 \\
\hline acca & 5.1 & Accumulation & m (ice equivalent) & Robert Arthern & Arthern et al., 2006 \\
\hline accr & 5.2 & Accumulation & m (ice equivalent) & Michiel van den Broeke & Van de Berg et al., 2006 \\
\hline ghfsr & 6.1 & Geothermal heat flux & $\mathrm{mW} \mathrm{m} \mathrm{m}^{-2}$ & Nicholas Shapiro & Shapiro and Ritzwoller, 2004 \\
\hline ghffm & 6.2 & Geothermal heat flux & $\mathrm{mW} \mathrm{m}^{-2}$ & Cathrine Fox Maule & Fox Maule et al., 2005 \\
\hline
\end{tabular}

means incorporates all the new data available. This considerable task is left for a "BEDMAP2", (an updated version of BEDMAP), however, the processing carried out in this document illustrates the requirements of a dataset for the purpose of high resolution ice sheet modelling, and bridges the gap until BEDMAP2 is published.

Whilst the ice sheet configuration datasets described here may be used for other purposes, the user should be aware that the focus of the data preparation was on assembling a dataset suitable for ice sheet modelling. For example, no claims are made about the accuracy of the sub ice-shelf interpolation, only that it is a "best guess" and it allows the ice shelf to float. This paper does not attempt to consider or quantify dataset errors, the reader is referred to original references for this.

The dataset presented here also includes the most up-todate versions of boundary conditions required to drive an Antarctic Ice Sheet model, namely, surface air temperature, accumulation and geothermal heat flux, and also a number of masks delineating the different parts of the ice sheet. This paper describes the data processing carried out to produce the final datasets: firstly, the masks and ice sheet configuration datasets are described (Sects. 2 and 3 respectively), then the surface air temperature (Sect. 4), the accumulation (Sect. 5) and finally the geothermal heat flux (Sect. 6).

\subsection{Dataset overview and format}

The dataset is available at doi:10.1594/PANGAEA.734145. Table 1 lists the data available in the overall dataset and provides an indication of the various sources of data. For a full description see the relevant section in this document.

The data are provided in a netcdf data format, see http: //www.unidata.ucar.edu/software/netcdf/ for more details of this data format. Many tools are available to convert the data. For example, ncdump, ncks, and nco can be used to extract ASCII data, Ncview, Panoply, and GMT could be used to view the data and mathematical operations can applied with NCO or GMT. In addition some commercial programs are also able to interpret netcdf files, tools to convert the data are available, for example, in Matlab and ArcGIS (9.2 onwards).

The data are on a $5 \mathrm{~km}$ resolution grid, in a Polar Stereographic Projection (Central Meridian, $0^{\circ}$, Standard Parallel, $71^{\circ} \mathrm{S}$ ) with respect to the EIGEN-GL04C geoid. The $5 \mathrm{~km}$ grid is 1160 columns by 1120 rows, the lower left corner (corner of the lower left cell) is $-2800 \mathrm{~km},-2800 \mathrm{~km}$. The nodata value is -9999 . Densities used are $1028 \mathrm{~kg} \mathrm{~m}^{-3}$ for ocean water and $918 \mathrm{~kg} \mathrm{~m}^{-3}$ for meteoric ice. 
Table 2. Mask values.

\begin{tabular}{lcl}
\hline Mask file & Value & Description \\
\hline mask & 0 & Ocean \\
mask & 1 & Grounded ice \\
mask & 2 & Ice shelf \\
mask+ & 0 & Non ice free/ice stream \\
mask+ & 3 & Ice free \\
mask+ & 4 & Ice stream $\left(>250 \mathrm{~m} \mathrm{yr}^{-1}\right)$ \\
glmask & 0 & Non "ice plain" \\
glmask & 5 & "Ice plain" \\
\hline
\end{tabular}

\section{Masks}

\section{1 "mask"}

The basic mask delineates ocean, grounded ice sheet and ice shelf regions of Antarctica. The mask is derived from the MOA (Mosaic of Antarctica) coastline shapefiles (Haran et al., 2005; Scambos et al., 2007). The ice thickness dataset (described later in Sect. 3.1.3) is composed of two separate datasets: the grounded ice sheet thickness, largely from BEDMAP, and ice shelf thickness, derived from the surface elevation and an assumption of hydrostatic equilibrium. In order to create a smooth join between the grounded and floating ice thickness datasets, a number of iterations are carried out where the mask (more specifically, the grounding line location) is modified to ensure the best join between the two datasets. Small changes are made away from ice stream grounding line areas, allowing for a one grid cell width smoothing boundary (see Sect. 3.1.3). Larger changes are made at a number of ice stream grounding zone locations, where the MOA grounding line is believed to be inaccurate. The areas of major change are discussed in Sect. 2.3 below.

Three islands were found to be missing from the original MOA dataset (Smyley Island and Case Island at the western end of George VI Ice Shelf, and Sherman Island incorporated in the Abbott Ice Shelf), these were added by digitising their extent from the original MOA image. The mask values are given in Table 2.

The mask was then modified to make it "modelling friendly", i.e. by removing small ice shelves ( 1 or 2 cells), and islands only one grid cell wide.

\section{2 "mask+"}

The purpose of the "mask+" mask is to provide extra information on the ice sheet, beyond that provided in the basic mask. It indicates terrestrial regions that are currently ice free (see Sect. 2.2.1 below) and ice stream regions, here defined by velocities over $250 \mathrm{~m} \mathrm{yr}^{-1}$ (see Sect. 2.2.2 below). Mask+ also contains the base values from "mask".

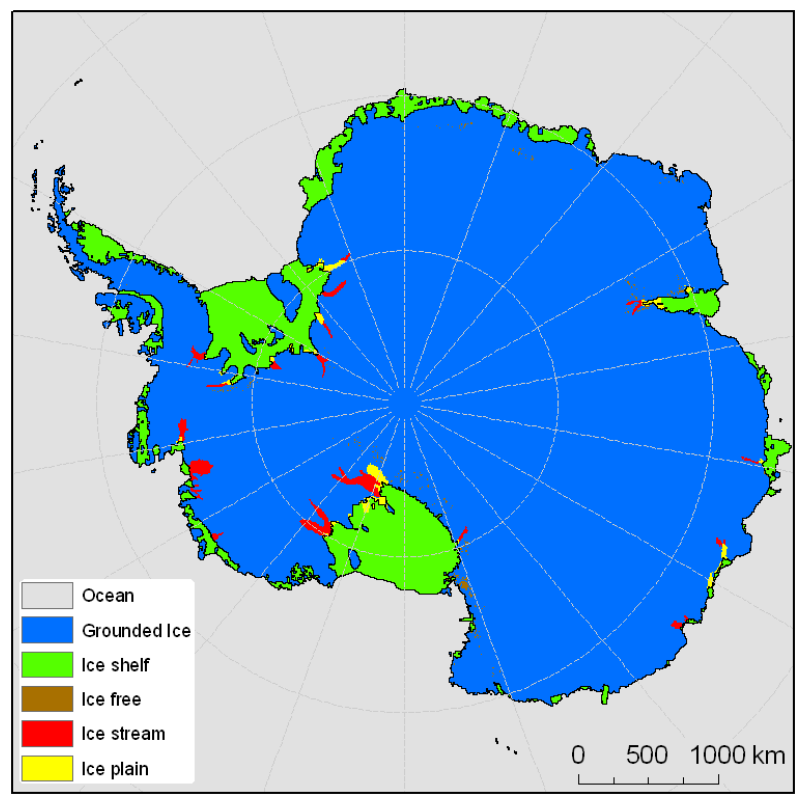

Figure 1. Combination of mask, mask+ and glmask.

\subsubsection{Ice free areas}

The ice free regions were derived from the ADD (Antarctic Digital Database) "rock" polygon coverage. The polygon coverage was converted to the $5 \mathrm{~km}$ grid, based on the percentage of the cell which is ice free (rock). A threshold of $33 \%$ of the cell being ice free was chosen, based on the resulting $5 \mathrm{~km}$ mask. Hence the $5 \mathrm{~km}$ ice free mask does not include all areas which are ice free, only those which cover a certain area.

\subsubsection{Ice stream areas}

The ice stream regions were derived from a combined map of InSAR velocities (Edwards, 2008). The InSAR velocity map does not cover all regions, hence some ice streams have been supplemented by balance velocities. The mask only includes the "major" ice streams, some small outlet glaciers are not coherent enough at a $5 \mathrm{~km}$ resolution, so have not been included (Fig. 1). Therefore the mask should only be considered indicative rather than definitive.

\section{3 "glmask"}

The glmask delineates differences between the ADD coastline polygon, the MOA polygon and the final mask provided in this dataset (Fig. 1). Hence, it delineates areas where there is some uncertainty in the grounding line location, i.e., areas where it is likely that there is an ice plain (an area where the ice is close to grounding/flotation). The original MOA grounding line is derived from the "break of slope" rather than the grounding line. In ice stream grounding zone areas, it is difficult to define a grounding line as such, and it 
is not the "break of slope", hence, the MOA mask is often a long way $(10 \mathrm{~s}$ of $\mathrm{km})$ inland from where it is believed to be (notably Pine Island Glacier, Slessor Glacier). The ADD grounding line is, therefore, more reliable in some ice stream regions (though generally much less reliable than MOA in other areas).

\section{Ice sheet configuration}

As mentioned in the introduction, the BEDMAP dataset provides information on the bed topography, bathymetry and ice thickness. However it contains a large number of inconsistencies, (e.g. bed plus ice thickness not equal to measured surface) and when a flotation calculation is carried out, it does not provide a grounding line consistent with observations. It is the aim of this section to produce a dataset that is free of these inconsistencies, suitable for initialising a numerical model for the present day ice sheet configuration. The following discussion outlines the important factors which need to be considered.

Firstly, at the most basic level, it is important that all the configuration datasets are self consistent, i.e. that if the surface elevation is derived from the bed and ice thickness, then it is consistent with the provided surface elevation.

Secondly, it is critical that if the mask says the ice is grounded, then it is grounded and likewise for floating ice. BEDMAP has a large number of ice shelf areas which become grounded due to poor sub ice-shelf interpolation. If the ice surface is derived by adding the ice thickness to the basal topography in areas which become grounded, then this will introduce a large number of grounded "islands" into the ice shelf areas.

Thirdly, around ice stream grounding zones, it is important that no modifications affect the ice sheet surface, e.g. changing the ice shelf thickness will change the resulting ice surface from a flotation calculation. The ice surface derived from any flotation calculation must be consistent with the measured surface, hence, in the ALBMAP dataset, the ice thickness in the ice shelf areas is derived from the ice surface and a firn correction. Any flotation calculation must include the firn correction and use the densities given here to ensure the ice sheet surface remains consistent. Otherwise, spurious bumps will appear, which will be highly noticeable in low slope ice stream regions.

Finally, it is also important that there are no false or large gradients in the ice surface, thickness or bed/bathymetry, as can arise when a number of datasets are combined. The consequence of this would be unfeasibly large gravitational driving stress (and hence velocities).

Figure 2 shows a flow diagram which works through the procedure carried out in this paper. The overall procedure consists of 7 steps which are documented further below. Firstly, the grounded and floating ice thickness datasets were joined, and the boundary smoothed to provide a smooth join.
Then a combined ice sheet surface DEM (Digital Elevation Model) was created, from two seperate DEMs. Next, the grounded ice sheet bed was derived from this surface and the combined thickness dataset. A check was then carried out to ensure that the ice is entirely grounded. All of the bathymetry datasets were then merged, the join smoothed in some regions, a flotation check was carried out, and areas where the ice is grounded were excavated.

\subsection{Ice thickness}

This section describes the merging of various sources of ice thickness data. Firstly, the merging of two grounded ice datasets is described (Sect. 3.1.1), then the merging of the grounded ice thickness with the floating ice shelf thickness (Sect. 3.1.2).

\subsubsection{Grounded ice}

Two versions of the ice thickness were produced, incorporating different published datasets. The basic version includes the original BEDMAP ice thickness (Lythe et al., 2001) and the AGASEA/BBAS Amundsen Sea data (Vaughan et al., 2006; Holt et al., 2006). A second version was also produced, incorporating the Recovery Glacier region inferred ice thickness of Le Brocq et al. (2008) in addition to the BEDMAP and AGASEA/BBAS data. The ice thickness data is included in the netcdf dataset in the form of the lower ice sheet surface (1srf and lsrf2) and topography (topg and topg2), derived from the ice thickness and ice surface topography. 1srf2 and topg2 refer to the second ice thickness version incorporating the Recovery Glacier region modification. This section describes the method used to join the ice thickness datasets.

Firstly, the BEDMAP ice thickness was smoothed using a low pass filter $(3 \times 3$ cell window), to remove spurious patterning present. It should be noted that the bed elevation dataset from BEDMAP is smooth in comparison to the ice thickness, so it is assumed that this was smoothed in the same way.

The region where there is dense coverage of RES (Radio Echo Sounding) flight lines in the AGASEA/BBAS dataset was identified, and the two datasets masked with a buffer zone where they overlap. The buffer zone has a width of $15 \mathrm{~km}$. In the buffer zone, the two ice thickness grids were averaged and then smoothed to ensure a smooth join in the final dataset.

For 1srf2 and topg2, the Le Brocq et al. (2008) ice thickness was merged with the BEDMAP data in the same way as the AGASEA/BBAS dataset.

The ice thickness at ice free locations (according to mask+) were set to zero. The ice thickness in areas which should be ice covered according to mask+, but were ice free, was calculated as the mean of their ice covered neighbours. If a location has no ice covered neighbours, the ice thickness was set to $50 \mathrm{~m}$ (see Table 3). 

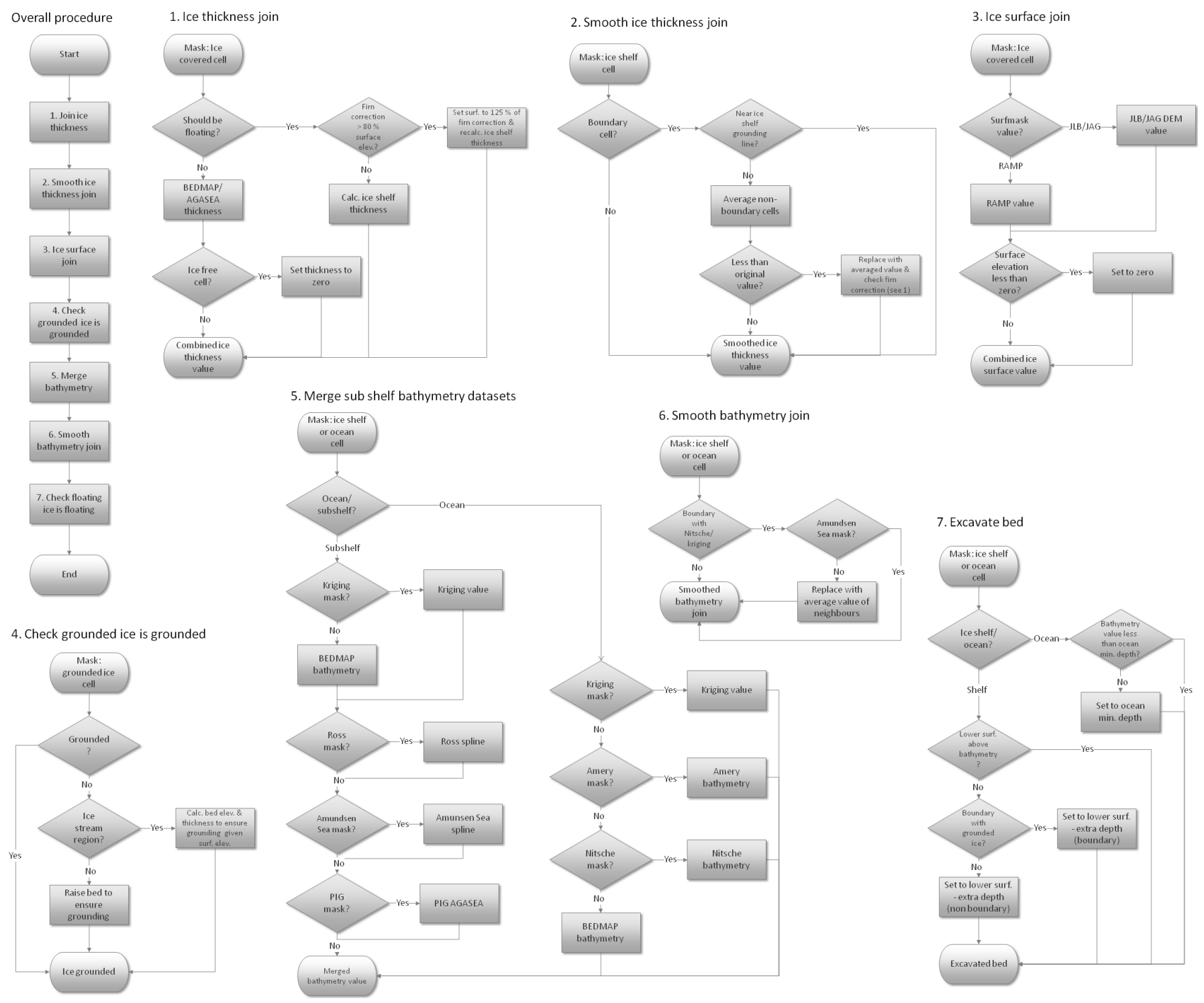

Figure 2. Flow diagram illustrating the processing procedure for the ice sheet configuration datasets.

Table 3. Summary of values used in the processing.

\begin{tabular}{ll}
\hline Description & Value \\
\hline Meteoric ice density $\left(\rho_{\mathrm{i}}\right)$ & $918 \mathrm{~kg} \mathrm{~m}^{-3}$ \\
Ocean density $\left(\rho_{\mathrm{w}}\right)$ & $1028 \mathrm{~kg} \mathrm{~m}^{-3}$ \\
Excavation extra depth $(d)$ & $20 \mathrm{~m}$ \\
Excavation extra depth $\left(\right.$ next to grounding line, $\left.d_{\mathrm{gl}}\right)$ & $1 \mathrm{~m}$ \\
Minimum ice thickness above buoyancy & $1 \mathrm{~m}$ \\
Default ice thickness where should be ice covered, but no ice covered neighbours & $50 \mathrm{~m}$ \\
Minimum ocean depth & $-10 \mathrm{~m}$ \\
Minimum ice free surface elevation & $10 \mathrm{~m}$ \\
\hline
\end{tabular}




\subsubsection{Floating ice}

Many ice shelves around Antarctica do not have measurements of ice thickness available for them. The BEDMAP dataset used a hydrostatic assumption to derive ice shelf thickness from surface elevations measured from satellite altimetry (see Fig. 3a for BEDMAP ice thickness). Since then, however, a new surface DEM has become available, incorporating IceSat laser altimetry data, as well as radar altimetry (Bamber et al., 2009; Griggs and Bamber, 2009a). In order to calculate the ice shelf thickness from the surface elevation, the respective densities of ocean water and ice need to be specified and an estimate of the depth and density of the firn layer is also required. Since the BEDMAP dataset was compiled, a spatial estimate of the firn correction for Antarctica has been produced using a regional climate model (RACMO, Van den Broeke et al., 2008, Fig. 3b). Therefore, the ice shelf thickness has been recalculated for the dataset presented in this paper.

The RACMO output (firn correction and accumulation) data were provided as lat-lon point measurements (equivalent resolution, $\sim 55 \mathrm{~km}$ ), these were reprojected onto the polar stereographic grid and interpolated onto the $5 \mathrm{~km}$ grid using spline interpolation. Values away from the ice sheet in the original data are zero, these were ignored in the interpolation, leading to non-zero values over the grid. However, beyond the present day ice sheet, they have no basis, and are purely a function of the interpolation method. Therefore, the datasets were masked using the $-2000 \mathrm{~m}$ bathymetry contour (to delimit the continental shelf) (Fig. 3b). Beyond the continental shelf, the mean value of the ice shelf firn values $(16.5 \mathrm{~m})$ is assigned.

Following Griggs and Bamber (2009b), the equivalent ice thickness $\left(H_{\mathrm{i}}\right.$, corresponding to the resulting ice thickness if all the ice column was at the density of meteoric ice) is given by

$H_{\mathrm{i}}=\frac{(s-f) \rho_{\mathrm{w}}}{\rho_{\mathrm{w}}-\rho_{\mathrm{i}}}$,

where $s$ is elevation above sea level, $f$ is a firn correction (defined as the difference between the actual depth of the firn layer and the depth that the firn would be if it was all at the density of meteoric ice), $\rho_{\mathrm{w}}$ is the density of sea water, $\rho_{\mathrm{i}}$ is meteoric ice density. The actual ice thickness $(H)$ is, therefore, the equivalent ice thickness $\left(H_{\mathrm{i}}\right)$ plus the firn correction $(f)$,

$H=H_{\mathrm{i}}+f$,

and, hence,

$H=\frac{(s-f) \rho_{\mathrm{w}}}{\rho_{\mathrm{w}}-\rho_{\mathrm{i}}}+f$.

It is the actual ice thickness $(H)$, i.e. meteoric ice thickness plus firn thickness, which is incorporated into the dataset (i.e. usrf - lsrf, Fig. 3c). Any flotation calculation in an icesheet model should incorporate the firn correction in the calculation.

Equations (1) and (3) assume a constant density for ocean water $\left(1028 \mathrm{~kg} \mathrm{~m}^{-3}\right)$ and ice $\left(918 \mathrm{~kg} \mathrm{~m}^{-3}\right)$. In areas where surface melt occurs the firn correction is likely to be overestimated (Griggs and Bamber, 2009b; Michiel Van den Broeke, personal communication), however this is unlikely to affect the major ice shelves.

In some areas the firn correction is greater than the surface elevation, generally around the periphery of ice shelves where there is a high degree of uncertainty in the surface elevation, or uncertainty as to whether shelf ice exists. Where the firn correction is greater than $80 \%$ of the surface elevation, the surface elevation is set to $125 \%(100 / 0.8)$ of the firn correction value, and the ice shelf thickness calculated from this surface. These areas are indicated in umask (value of 4).

\subsubsection{Joining ice thickness datasets}

The grounded ice thickness and the ice shelf thickness must be joined smoothly to avoid any steep gradients in ice thickness. However, in order to maintain the consistency between the ice thickness and the ice surface in the ice shelf regions, the ice thickness cannot be smoothed in grounding line regions of the major ice streams. Hence, there is no smoothing carried out across the major ice stream grounding lines in the dataset presented here.

Away from the major ice stream grounding lines, the break in slope at the grounding line is more obvious and the surface DEM is less reliable due to "loss of lock" in the radar altimetry data (Griggs and Bamber, 2009a). This leads to a "contamination" of the surface heights in ice shelf regions close to the grounding line, and causes larger errors in the surface elevations and hence potentially elevated ice thicknesses. Ice thickness values in ice shelf cells that are on a border with the grounded ice were smoothed (average of "non-border" neighbours). The original value was then replaced with the smoothed value if the smoothed value was less than the original. This removes the spuriously high ice thickness values introduced at the grounding line by errors in the surface DEM (see Fig. 3d). A similar check to that in Sect. 3.1.2 was carried out to make sure that the smoothed ice thickness values were sufficient to lead to a surface elevation value greater than $125 \%$ of the firn correction.

\subsection{Ice surface}

This section describes the ice surface DEM. The combined DEM is largely derived from the DEM of Bamber et al. (2009) (JLB/JAG DEM), however there are some modifications made at this stage and changes result from the changes to the ice shelf thickness (descibed above in Sect. 3.1.3). The DEM is a combination of the JLB/JAG DEM (non-Antarctic Peninsula) and the RAMP 


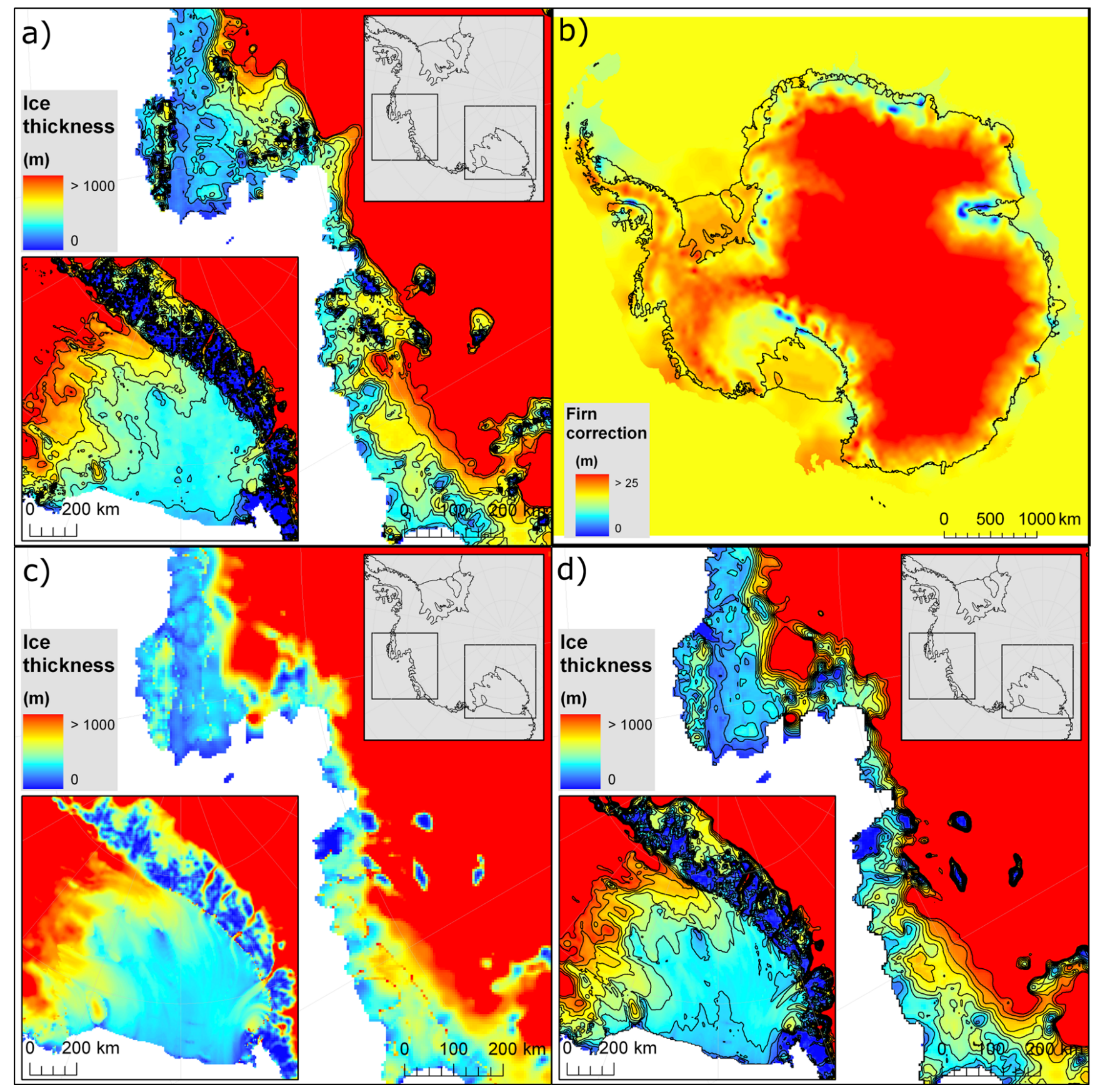

Figure 3. Ice thickness join: (a) original BEDMAP ice thickness, (b) firn correction used in calculating the floating ice thickness, (c) unsmoothed combined grounded and floating ice thickness and (d) smoothed combined grounded and floating ice thickness. Contours show $100 \mathrm{~m}$ thickness intervals (up to $1000 \mathrm{~m}$ ), they are not shown on (c) for clarity in showing the join between floating and grounded ice thickness datasets.

DEM (Antarctic Peninsula, Liu et al., 1999). The JLB/JAG DEM is derived solely from radar and laser altimetry, hence, the coverage is sparse over the Antarctic Peninsula and the DEM does not look realistic (Fig. 4a). The RAMP DEM incorporates ADD elevation data over the Antarctic Peninsula, and whilst this also has large inherent errors, it is probably more accurate than the JLB/JAG DEM. The two were com- bined in grounded ice regions only, using the mask shown in Fig. 4. The version of the JLB/JAG DEM used in the dataset presented here differs slightly from the published version, using a tension spline interpolation technique instead of kriging. The tension spline version is smoother, but may miss some high resolution spatial features. 


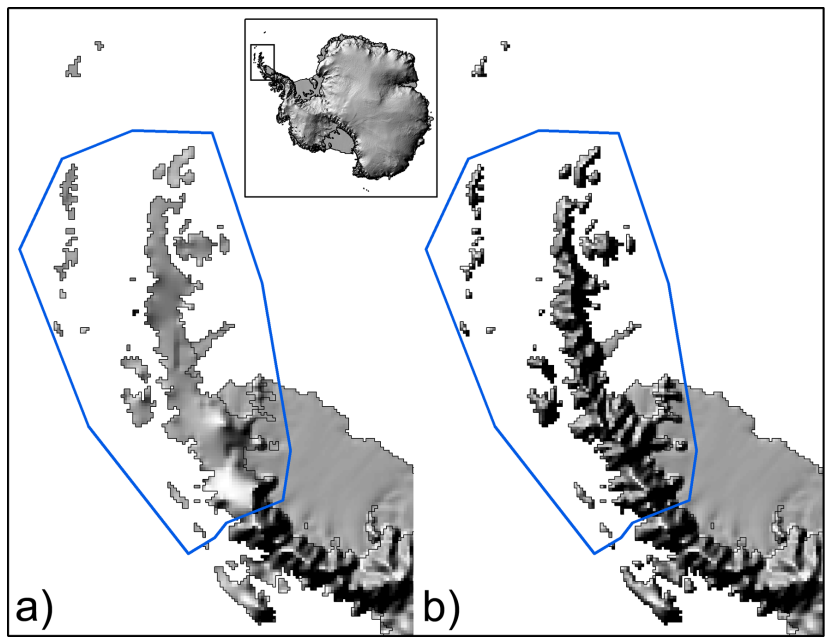

Figure 4. Ice surface join: (a) hillshade of JLB/JAG DEM and (b) hillshade of combined DEM.

At this stage, the ice surface DEM is used, in combination with the ice thickness, to calculate the bed elevation in grounded areas of the ice sheet. Later, the surface elevation is re-calculated for ice shelf regions, and will differ from the original DEM, due to the ice thickness smoothing that occurred in Sect. 3.1.3. Small areas of the ice surface DEM, in grounded regions, are artificially raised in the next section, however these are not in ice stream regions, and generally are in areas where the DEM error is high.

\subsection{Grounded ice covered bed}

The bed elevation in the grounded ice region was derived by subtracting the grounded ice thickness (Sect. 3.1.1) from the combined ice surface dataset (Sect. 3.2). The ice thickness above buoyancy $\left(H^{*}\right)$ was calculated using

$H^{*}=(H-f)+\left(\rho_{\mathrm{w}} / \rho_{\mathrm{i}}\right) h$,

where $h$ is bed elevation, and checked to ensure that the ice is grounded (where $H^{*} \geq 0$ ). There are two different areas where this may not be the case and these are treated separately:

1. where the ice surface/thickness is not confidently known, and away from major ice stream grounding lines. In these areas the bed elevation is increased to ensure the ice is grounded, hence the ice surface elevation is altered. These areas are indicated with a value of 4 in umask, there are 544 grid cells which are altered, around $0.1 \%$ of the grounded ice cells.

2. ice stream areas, where it is important to keep the ice surface elevation the same as the DEM. In these regions the bed elevation and thickness needed to cause grounding, is calculated by rearranging Eq. (4) in terms of the actual ice thickness $(H)$ and surface elevation $(s)$, where the surface elevation is taken from the surface DEM:

$H=\frac{H^{*}+f-\left(\rho_{\mathrm{w}} / \rho_{\mathrm{i}}\right) s}{1-\left(\rho_{\mathrm{w}} / \rho_{\mathrm{i}}\right)}$,

where $H^{*}$ here is set to $1 \mathrm{~m}$.

The bed elevation $(h)$ is then derived from

$h=s-H$.

Ice free areas (see mask + ) were checked to ensure that the bed elevation is above sea level, and their elevation set to a given elevation $(10 \mathrm{~m})$ if not.

\subsection{Sub ice-shelf bathymetry}

Away from the main ice shelves (e.g. Ross, Filchner-Ronne), there is very limited data on the sub ice-shelf bathymetry in BEDMAP. The interpolation algorithms employed by BEDMAP led to sub ice-shelf bathymetry values that caused many ice shelves to ground. This section describes the methods used to reinterpolate various areas of sub ice-shelf bathymetry. It should be emphasised here that the BEDMAP gridded datsets have been used for the reinterpolation, rather than the original BEDMAP database of measurements. The most straightforward method to ensure the ice shelves float would be to simply excavate a certain depth beneath the lower surface of the ice shelf, however this would lead to a uniform cavity depth, and this would not be realistic. The approach taken here is to carry out a slightly "supervised" approach to the reinterpolation, identifying the problem areas, and tailoring the interpolation methods to each area. The bathymetry still requires excavation in certain areas, this is described in Sect. 3.4.6. The following sections describe the interpolation procedures for different areas: small ice shelves around East Antarctica (Sect. 3.4.1), the Ross Ice Shelf near the Transantarctic Mountains (Sect. 3.4.2), the Amundsen Sea region (Sect. 3.4.3), PIG (Pine Island Glacier) sub ice-shelf (Sect. 3.4.4) and the Amery sub ice-shelf region (Sect. 3.4.5).

It should be noted that the original BEDMAP bathymetry was on a slightly different coordinate reference than the BEDMAP ice thickness. When comparing the bathymetry with other datasets, it also appeared to be slightly offset. As a result, the BEDMAP bathymetry was shifted by $-3134 \mathrm{~m}$ in the $\mathrm{x}$-direction and $1866 \mathrm{~m}$ in the $\mathrm{y}$-direction to remove this apparent shift and set the bathymetry grid's spatial reference to be the same as the ice thickness grid.

\subsubsection{General (sub ice-shelf) bathymetry}

The bathymetry in BEDMAP beneath the small ice shelves fringing the ice sheet (see red outline in Fig. 5) is very shallow. Therefore, the bathymetry in these regions was reinterpolated, however the reinterpolation is not applied where 


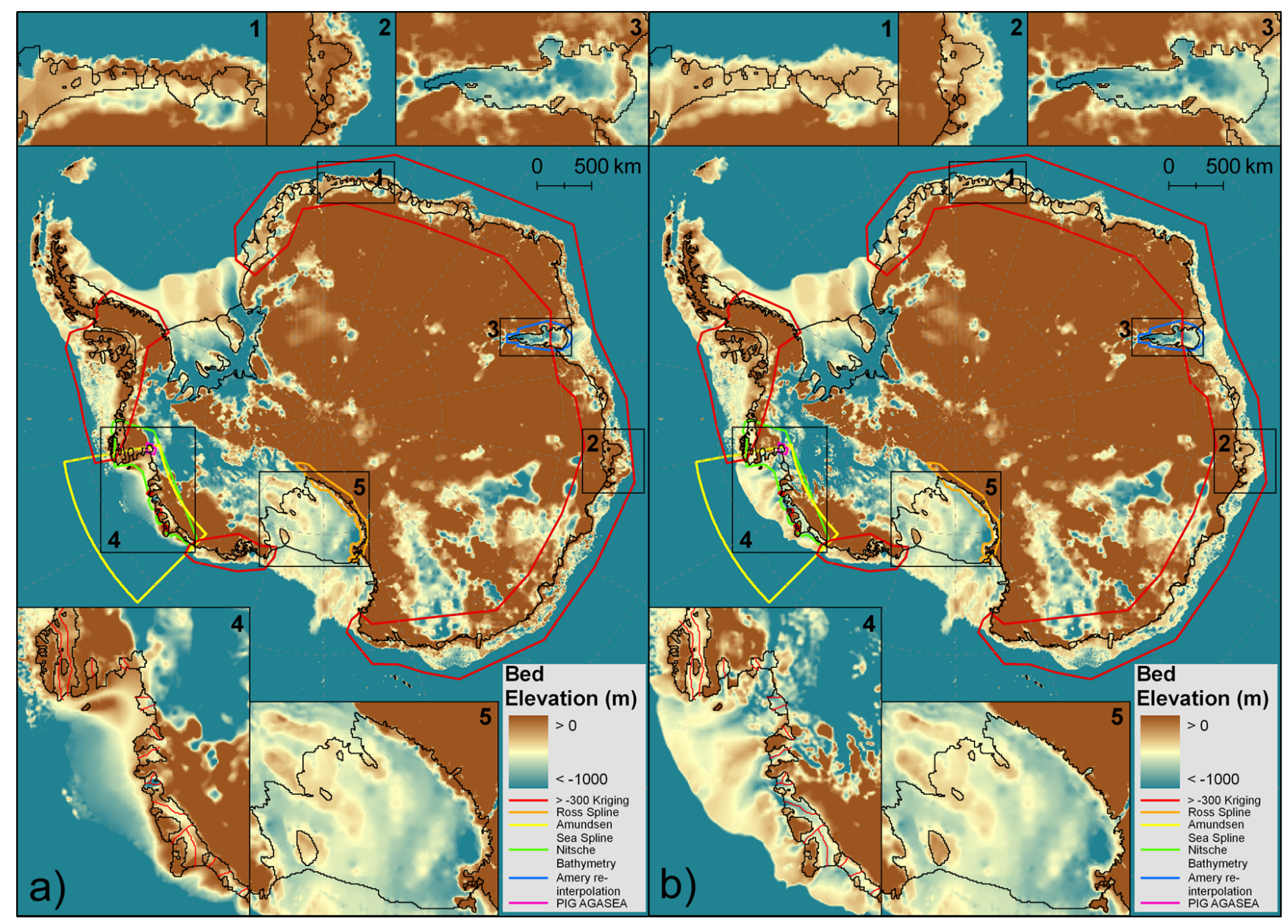

Figure 5. Bed/bathymetry, coloured lines indicate masks where data was replaced: (a) original BEDMAP bed and bathymetry and (b) improved dataset. Insets show regions of interest described in the text: 1) and 2) General bathymetry, 3) Amery ice shelf, 4) Amundsen Sea region and 5) Ross Ice Shelf.

the mask overlies the major ice shelves (Ross/FilchnerRonne/Amery), as these are better constrained by observation, or for ice shelves in the Amundsen Sea region, which are reinterpolated using a different method (see Sect. 3.4.3).

All ice shelf areas within the red outline shown in Fig. 5 were set to nodata, also, where the ocean bathymetry elevations were higher than $-300 \mathrm{~m}$, the elevation was set to nodata. The nodata values were then reinterpolated (using both grounded bed and bathymetry $<-300 \mathrm{~m}$ ) using kriging to produce deeper bathymetry (see Fig. 5).

\subsubsection{Ross Ice Shelf}

Near the Tranantarctic mountains, beneath the western Ross Ice Shelf, there are very few data available on the bathymetry. As a result, in combination with the Inverse Distance Weighting (IDW) interpolation used in BEDMAP, there is some "leakage" of the high elevations into the sub ice-shelf region. This can be avoided by using a spline interpolation technique, which would take into account the steep slope of the mountains towards the sub ice-shelf region, into the deep sub ice-shelf bathymetry. The most erroneous area was identified by eye (see orange outline in Fig. 5). The area was then reinterpolated using a tension spline with a high weighting and high number of points in order to force the sub ice-shelf region near to the mountains to have a steep elevation gradient, which levels off into a deep, lower gradient surface away from the mountains (Fig. 5, inset 5).

\subsubsection{Amundsen Sea Ice Shelves}

Since the BEDMAP dataset was created, a large amount of new bathymetry data have become available for the Amundsen Sea region, these data were compiled by Nitsche et al. (2007) (see Sect. 3.5.1). These bathymetry data are useful for re-interpolating the Amundsen Sea sub iceshelf bathymetry, as they provide new information on the bathymetry at ice shelf fronts. In order to utilise this, the 
data were combined with the grounded ice sheet bed from Sect. 3.3 and the BEDMAP bathymetry beyond the Nitsche dataset. The sub ice-shelf regions were then reinterpolated using a novel approach which allows the incorporation of the bathymetry data away from the ice shelf fronts.

The Nitsche et al. (2007) bathymetry suggests that the sub ice-shelf bathymetry is reasonably deep, with "trough" like features in the sub ice-shelf regions. As with the Ross Ice Shelf bathymetry (Sect. 3.4.2), this morphology lends itself to spline interpolation. However, away from the areas with ocean bathymetry data, even spline interpolation may lead to too shallow sub ice-shelf bathymetry and cause the ice shelves to ground.

Therefore, in order to aid the interpolation process, the "bottoms" of the troughs were imposed as a function of the ocean bathymetry at one end of a transect, and the grounded ice bed elevation at the other. A series of transects were constructed (see red lines on Fig. 5, inset 4) and the sub ice-shelf bathymetry value, along the transect, calculated as a linear function of distance from either the ocean end of the transect, or the grounded ice sheet end. Where two transects join, as beneath the Getz ice shelf, the transect connected to both the ocean and grounded bed is interpolated first, then the connecting transect uses the newly interpolated value at its connected end. These values were then combined with the masked bed/bathymetry data outside of ice shelf areas, and a spline interpolation carried out. The result is very different from BEDMAP, and leads to deep sub ice-shelf cavities around the Amundsen Sea.

\subsubsection{PIG Ice Shelf}

Part of the PIG sub ice-shelf is treated differently to the rest of the Amundsen Sea ice shelves. Directly in front of PIG itself there is a trench connecting the ocean with the base of the ice stream. Rather than simply linearly interpolating the trench as in Sect. 3.4.3, the original AGASEA/BBAS data are used solely in the "trench". Subsequent to this processing, a sub ice-shelf ridge has been identified (Jenkins et al., 2009).

\subsubsection{Amery Ice Shelf}

Whilst there are some data available for the sub ice-shelf bathymetry in the Amery Ice Shelf region in BEDMAP, there is also a large amount derived from interpolation, leading to a "ridge" appearing towards the coastal end of the ice shelf. Recent data suggests that this ridge does not exist (Galton-Fenzi et al., 2008), hence some reinterpolation has been carried out in the dataset presented in this paper. All bathymetry (sub ice-shelf and ocean) in BEDMAP that was above $-600 \mathrm{~m}$ was reinterpolated using kriging, and replaced in the masked area shown on Fig. 5 (blue outline, also inset 3), chosen to ensure a smooth join between the other datasets.

\subsubsection{Excavation}

In order to ensure that all the ice shelf regions will be floating, the bed was excavated in areas where the lower ice surface was below the bathymetry elevation (and the extra depth, see below) using

$h=s-H-d$,

(where $s$ has been recalculated using the smoothed ice thickness (using Eq. 3)), for cells not in proximity to grounded ice, where $d$ is the extra depth specified beneath the ice shelf (20 $\mathrm{m}$, see Table 3 ) and

$h=s-H-d_{\mathrm{gl}}$,

for cells with a boundary with grounded ice, where $d_{\mathrm{gl}}$ is extra depth specified beneath the ice shelf next to grounding lines ( $1 \mathrm{~m}$, see Table 3 ).

\subsection{Ocean bathymetry}

The ocean bathymetry (excluding sub-ice shelf areas) is largely the same as BEDMAP except in two areas, the Amundsen Sea and continental shelf areas as described in Sect. 3.4.1. This section describes the processing carried out in these regions.

\subsubsection{Nitsche bathymetry}

The BEDMAP bathymetry contains very few data from observations in the Amundsen Sea region. The bathymetry dataset of Nitsche et al. (2007) is based on recent shipbased observations and provides a great improvement in the Amundsen Sea region. The published lat-lon data were reprojected onto the polar stereographic grid and interpolated onto the $5 \mathrm{~km}$ grid (see Fig. 5 for the result).

\subsubsection{General (ocean) bathymetry}

There are many ocean regions bordering ice shelves (particularly in East Antarctia) which have elevations close to sea level (see Fig. 5, insets 1 and 2). This is not appropriate, as, if the ice shelves were to advance they would simply ground on these shallow regions and would not therefore flow in a realistic manner. There are very few data for the ocean bathymetry in these regions, hence, it is reasonable to carry out the same interpolation procedure as in the sub ice-shelf section (Sect. 3.4.1).

\subsubsection{Final checks}

In the Antarctic Peninsula region, a large area which should be below sea level is above sea level (according to the MOA mask), but was not reinterpolated in Sect. 3.5.2. Any ocean regions that have elevations above $-10 \mathrm{~m}$ were set to $-10 \mathrm{~m}$. 
Table 4. Summary of bmask values.

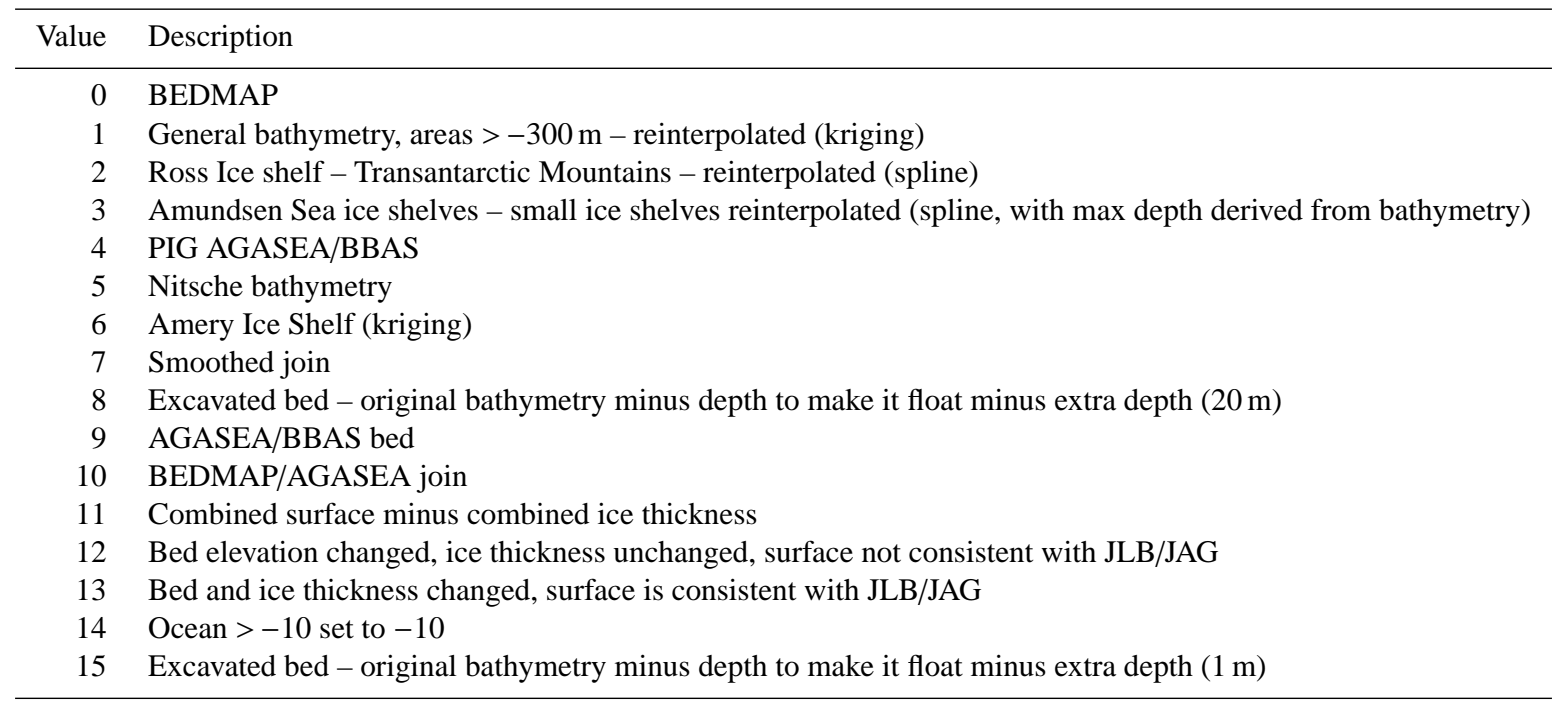

Table 5. Summary of umask values.

\begin{aligned} & \hline Value Description \\ & \hline 0 Ocean \\ & 1 Ramp surface \\ & 2 JLB/JAG surface grounded \\ & 3 JLB/JAG surface floating \\ & 4 Ice shelf areas not consistent with JLB/JAG surface (firn correction greater than surface) \\ & 5 Ice shelf thickness join smoothed and replaced if less than original \\ & 6 Shelf thickness changed because less resulting surface less than firn correction (post smoothing) \\ & 7 Missing/negative grounded ice thickness smoothed \\ & 8 Missing/negative grounded ice thickness replaced with 50 m \\ & 9 Ice free areas, ice thickness set to zero \\ & 10 Non-grounded ice: bed elevation changed, ice thickness unchanged, surface not consistent with JLB/JAG \\ & 11 Non-grounded ice: bed \& ice thickness changed, surface is consistent with JLB/JAG \\ & \hline\end{aligned}

\subsection{Summary of configuration datasets}

The grids bmask and umask summarise the processing which has been carried out on the bed/bathymetry and ice surface/thickness configuration datasets respectively. Tables 4 and 5 detail the values provided in these masks.

Figure 6 shows the ice thickness above buoyancy for the original BEDMAP ice sheet configuration (Fig. 6a) and for the new dataset (Fig. 6b). The new dataset provides a much more consistent agreement with the grounding line suggested by the MOA dataset than BEDMAP.

\section{Surface temperature}

The surface air temperature dataset is described in Comiso (2000). The surface temperature estimates are derived from
AVHRR infrared data. Annual mean temperatures from 1982-2004 were averaged to provide the surface air temperature field (Fig. 7a). The AVHRR data is currently available on a monthly basis at a resolution of $6.25 \mathrm{~km}$ from November 1978 to mid-2009 as part of an ongoing project.

\section{Accumulation}

\subsection{Arthern et al. (2006)}

The accumulation dataset of Arthern et al. (2006) was derived from interpolation of in situ point measurements, i.e. snow pits, ice cores and stake measurements. Passive microwave satellite data (firn emissivity) were used as a "forcing field" to control the interpolation. The original data were supplied at a resolution of $25 \mathrm{~km}$. The data were, here, 


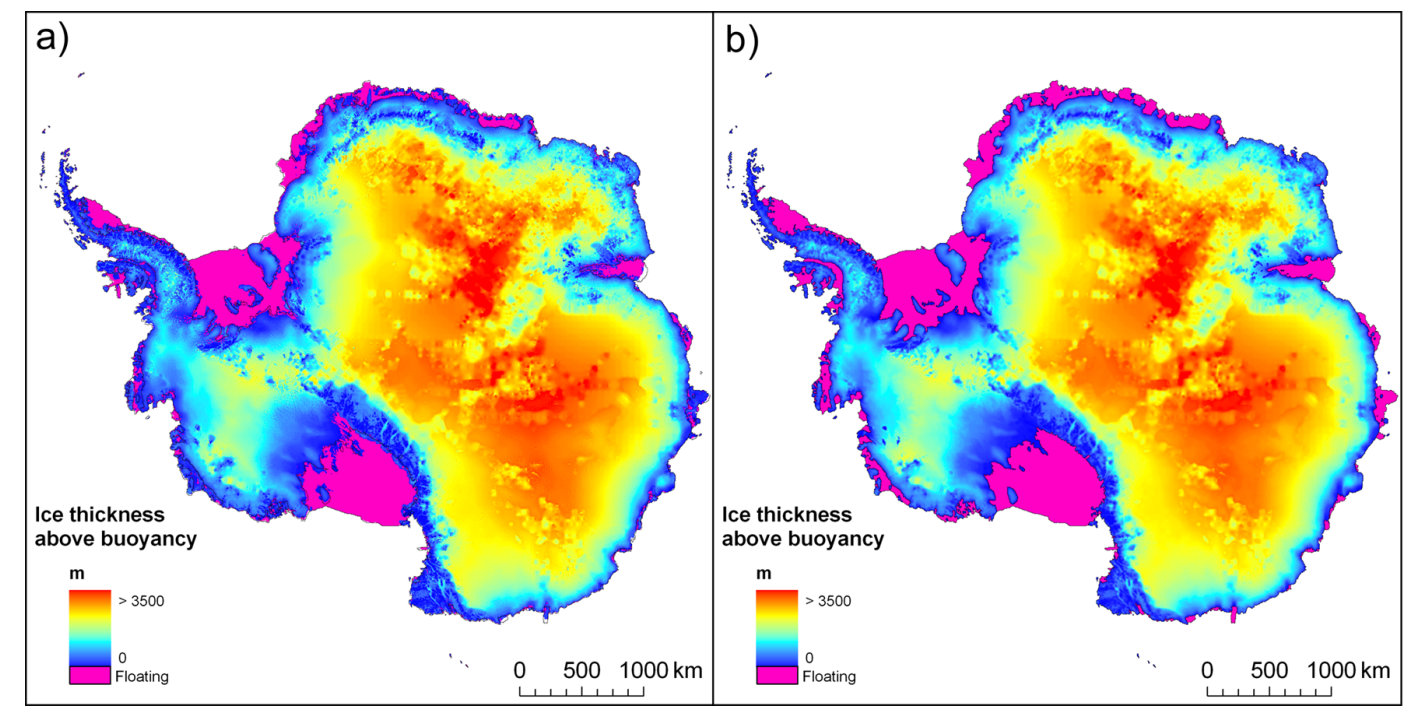

Figure 6. Ice thickness above buoyancy: (a) original BEDMAP dataset and (b) ALBMAP dataset.
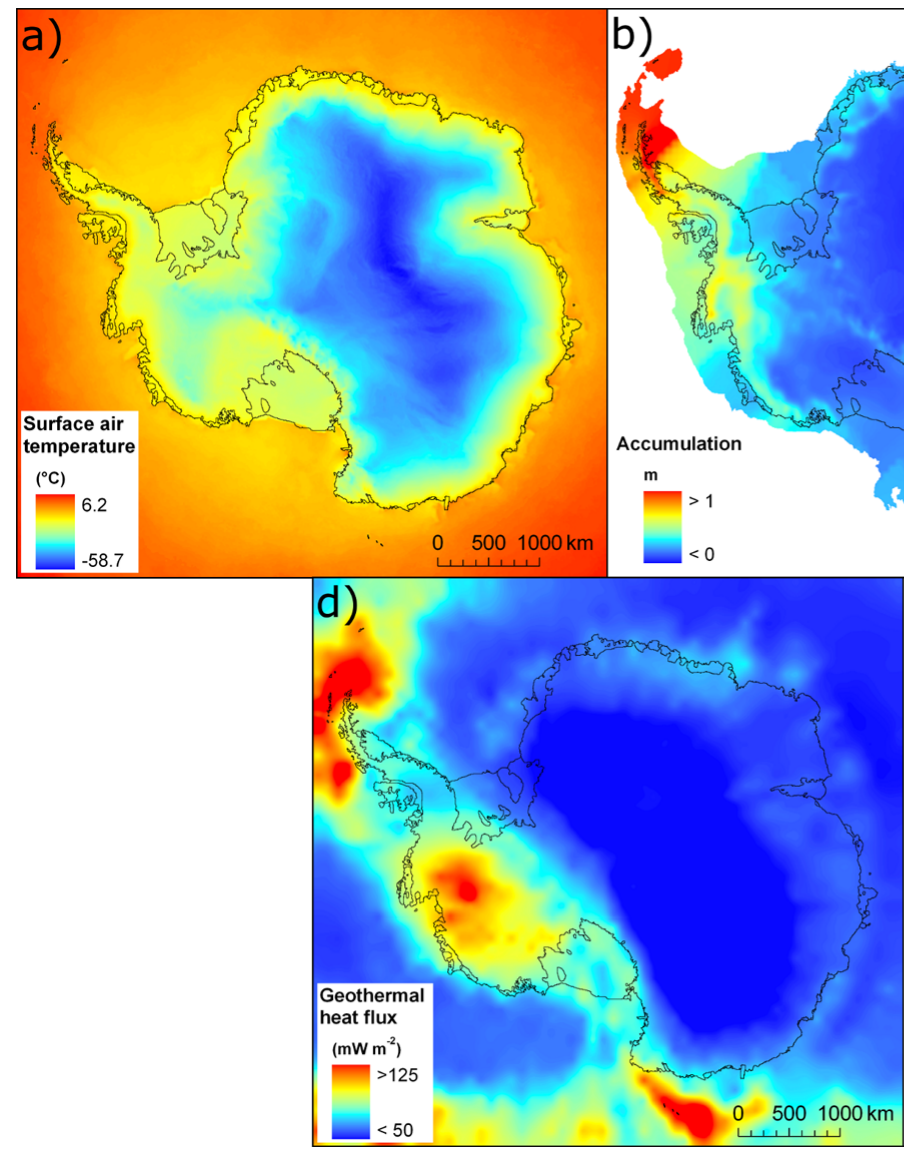
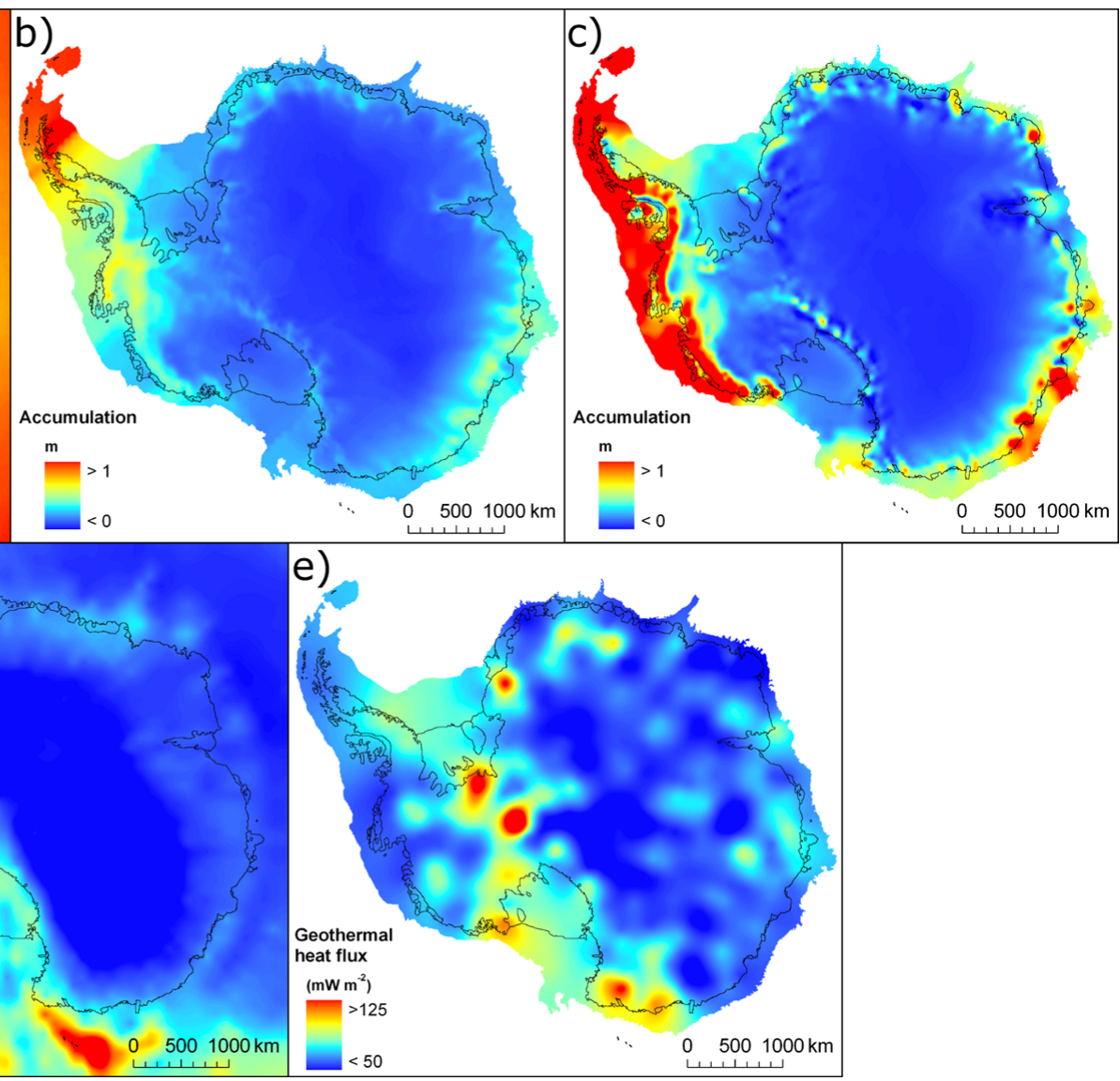

Figure 7. Other datasets provided: (a) surface air temperature, (b) accumulation (Arthern et al., 2006), (c) accumulation (Van de Berg et al., 2006), (d) geothermal heat flux (Shapiro and Ritzwoller, 2004) and (d) geothermal heat flux (Fox Maule et al., 2005). 
interpolated onto the $5 \mathrm{~km}$ grid using spline interpolation. In the original dataset there is no data beyond the ice sheet, however, it would be useful to have values beyond the present day ice sheet. Hence, the accumulation data was extrapolated beyond the present day ice sheet, though these values have no physical basis, and are purely the result of extrapolation from the ice covered values, and the interpolation method used, so should be used with caution. The accumulation dataset was masked using the $-2000 \mathrm{~m}$ bathymetry contour (to provide data beyond the present day ice sheet, but to limit it to the continental shelf) (Fig. 7b).

\subsection{Van de Berg et al. (2006)}

The accumulation dataset of Van de Berg et al. (2006) is an output from the RACMO regional model (Van de Berg et al., 2006). The accumulation is generally higher than that of Arthern et al. (2006), especially in data-sparse areas. The integrated accumulation exceeds previous estimates by up to $15 \%$. The data were provided as lat-lon point measurements, these were reprojected onto the polar stereographic grid and interpolated onto the $5 \mathrm{~km}$ grid using spline interpolation (Fig. 7c). The dataset was masked using the $-2000 \mathrm{~m}$ bathymetry contour in the same way as the Arthern et al. (2006) accumulation, again, areas beyond the present day ice sheet are a result of the extrapolation process and the interpolation method used.

\section{Geothermal heat flux}

Two geothermal heat flux maps are provided in this dataset, that differ greatly from each other. The method of derivation is briefly described here and also the method of gridding the data. Note that the heat flux values are positive, some ice sheet models (including Glimmer-CISM), require these values to be negative.

\subsection{Shapiro and Ritzwoller (2004)}

Shapiro and Ritzwoller (2004) use a global seismic model of the crust and upper mantle to extrapolate existing heat flux measurements to areas where there are few data, using a "structural similarity function". The original data are gridded on a geographic (lat-lon) grid, so when they are projected to a polar stereographic projection, this creates problems in gridding straight to $5 \mathrm{~km}$ resolution, due to the directionality of the points used in the interpolation procedure. The gridding introduces elongated features which are not present in the original data.

The effective resolution of the data (in latitude anyway) is $\sim 100 \mathrm{~km}$. Therefore the data were first gridded on to a $100 \mathrm{~km}$ grid using spline interpolation. The $100 \mathrm{~km}$ grid points were then reinterpolated, again using spline interpolation, onto the $5 \mathrm{~km}$ grid (Fig. 7d). This reduces the elon- gated features whilst retaining most of the detail in the original dataset.

\subsection{Fox Maule et al. (2005)}

The geothermal heat flux dataset of Fox Maule et al. (2005) was derived from satellite magnetic data and a thermal model. The point data provided were interpolated on to the $5 \mathrm{~km}$ grid using spline interpolation. The dataset was then masked using the $-2000 \mathrm{~m}$ bathymetry contour buffer described in Sect. 5, as the points are limited to the grounded ice regions of Antarctica (Fig. 7e).

\section{Summary}

This document has detailed the steps taken in order to create a dataset suitable for high resolution numerical ice sheet modelling. It is hoped that not only will the dataset be useful to the ice sheet modelling community, but also that the need for consistency within the ice sheet configuration datasets has been demonstrated. The importance of a consistent ice sheet surface across the grounding line cannot be emphasised strongly enough, as well as the importance of a correct grounding line location. If a model is to accurately predict the future evolution of the ice sheet/ice streams it is important that the response is not just the model responding to inaccuracies in the input data. Whilst these will never be eradicated, it is important that they are minimised as far as possible.

Acknowledgements. Thanks to those that have made their data available directly or indirectly for this project, and given assistance in the construction of this dataset. It is impossible to name all the contributors here, however Jennifer Griggs, Robert Arthern, Jonathan Bamber, Josefino Comiso, Laura Edwards, Cathrine Fox Maule, Frank Nitsche, Nicholai Shapiro, Ralph Timmerman, Michiel Van den Broeke, David Vaughan and Pippa Whitehouse have made specific contributions to the data and this manuscript.

Anne Le Brocq acknowledges funding from a UK Natural Environment Research Council (NERC) grant NE/E006108/1. Antony Payne acknowledges the support of the National Centre for Earth Observation. The work was also greatly helped by collaboration within the framework of the EU Framework 7 project ice2sea.

Edited by: O. Eisen

\section{References}

Arthern, R. J., Winebrenner, D. P., and Vaughan, D. G.: Antarctic snow accumulation mapped using polarization of $4.3-\mathrm{cm}$ wavelength microwave emission, J. Geophys. Res.-Atmos., 111, D06107, doi:10.1029/2004JD005667, 2006.

Bamber, J. L., Gomez-Dans, J. L., and Griggs, J. A.: A new 1 km digital elevation model of the Antarctic derived from combined satellite radar and laser data - Part 1: Data and methods, The Cryosphere, 3, 101-111, doi:10.5194/tc-3-101-2009, 2009. 
Comiso, J. C.: Variability and trends in Antarctic surface temperatures from in situ and satellite infrared measurements, J. Climate, 13(10), 1674-1696, 2000.

Edwards, L. A.: Satellite Interferometry and Tracking data: Antarctic Velocity Map Generation, Validation and Application, Unpublished PhD thesis, University of Bristol, UK, 2008.

Fox Maule, C., Purucker, M., Olsen, N., and Mosegaard, K.: Heat flux anomalies in Antarctica revealed by satellite magnetic data, Science, 309, 464-467, 2005.

Galton-Fenzi, B. K., Maraldi, C., Coleman, R., and Hunter, J.: The cavity under the Amery Ice Shelf, East Antarctica, J. Glaciol., 54(188), 881-887, 2008.

Griggs, J. A. and Bamber, J. L.: A new 1 km digital elevation model of Antarctica derived from combined radar and laser data - Part 2: Validation and error estimates, The Cryosphere, 3, 113-123, doi:10.5194/tc-3-113-2009, 2009a.

Griggs, J. A. and Bamber, J. L.: Ice shelf thickness over Larsen C, Antarctica, derived from satellite altimetry, Geophys. Res. Lett., 36, L19501, doi:10.1029/2009GL039527, 2009b.

Haran, T., Bohlander, J., Scambos, T., Painter, T., and Fahnestock, M. (compilers): MODIS mosaic of Antarctica (MOA) image map, Boulder, Colorado, USA, National Snow and Ice Data Center, Digital media, 2005 (updated 2006).

Holt, J. W., Blankenship, D. D., Morse, D. L., Young, D. A., Peters, M. E., Kempf, S. D., Richter, T. G., Vaughan, D. G., and Corr, H. F. J.: New boundary conditions for the West Antarctic Ice Sheet: Subglacial topography of the Thwaites and Smith glacier catchments, Geophys. Res. Lett., 33, L09502, doi:10.1029/2005GL025561, 2006.

Hubbard, A., Bradwell, T., Golledge, N., Hall, A., Patton, H., Sugden, D., Cooper, R., and Stoker, M.: Dynamic cycles, ice streams and their impact on the extent, chronology and deglaciation of the British-Irish ice sheet, Quaternary Sci. Rev., 28(7-8), 758-776, 2009.

Jenkins, A., Dutrieux, P., Mcphail, S., Perrett, J., Webb, A., White, D., and Jacobs, S. S.: Bathymetry and ocean properties beneath Pine Island Glacier revealed by Autosub3 and implications for recent ice stream evolution, Eos Trans. AGU, 90(52), Fall Meet. Suppl., Abstract C31F-03, 2009.

Le Brocq, A. M., Hubbard, A., Bentley, M. J., and Bamber, J. L.: Subglacial topography inferred from ice surface terrain analysis reveals a large un-surveyed basin below sea level in East Antarctica, Geophys. Res. Lett., 34, L16503, doi:10.1029/2008GL034728, 2008.

Liu, H., Jezek, K., and Li, B.: Development of an Antarctic digital elevation model by integrating cartographic and remotely sensed data: A geographic information system based approach, J. Geophys. Res., 104(B10), 23199-23213, 1999.
Lythe, M. B., Vaughan, D. G.. and the BEDMAP Consortium: BEDMAP: A new ice thickness and subglacial topographic model of Antarctica, J. Geophys. Res.-Sol. Ea., 106(B6), 1133511351, 2001.

Meehl, G. A., Stocker, T. F., Collins, W. D., Friedlingstein, P., Gaye, A. T., Gregory, J. M., Kitoh, A., Knutti, R., Murphy, J. M., Noda, A., Raper, S. C. B., Watterson, I. G., Weaver, A. J., and Zhao, Z.-C.: Global Climate Projections, in: Climate Change 2007: The Physical Science Basis, Contribution of Working Group I to the Fourth Assessment Report of the Intergovernmental Panel on Climate Change, edited by: Solomon, S., Qin, D., Manning, M., Chen, Z., Marquis, M., Averyt, K. B., Tignor, M., and Miller, H. L., Cambridge University Press, Cambridge, UK and New York, NY, USA, 2007.

Nitsche, F.O., Jacobs, S., Larter, R. D., and Gohl, K.: Bathymetry of the Amundsen Sea continental shelf: Implications for geology, oceanography, and glaciology, Geochem. Geophy. Geosy., 8, Q10009, doi:10.1029/2007GC001694, 2007.

Pattyn, F.: Transient glacier response with a higher-order numerical ice-flow model, J. Glaciol., 48(162), 467-477, 2002.

Pollard, D. and DeConto, R. M.: Modelling West Antarctic ice sheet growth and collapse through the past five million years, Nature, 458(7236), 329-333, 2009.

Price, S. F., Waddington, E. D., and Conway, H.: A full-stress, thermomechanical flowband model using the finite volume method, J. Geophys. Res., 112, F03020, doi:10.1029/2006JF000724, 2007.

Scambos, T. A., Haran, T. M., Fahnestock, M. A., Painter, T. H., and Bohlander, J.: MODIS-based Mosaic of Antarctica (MOA) data sets: Continent-wide surface morphology and snow grain size, Remote Sens. Environ., 111(2-3), 242-257, 2007.

Schoof, C.: Ice sheet grounding line dynamics: Steady states, stability, and hysteresis, J. Geophys. Res., 112(F3), F03S28, doi:10.1029/2006JF000664, 2007.

Shapiro, N. M. and Ritzwoller, M. H.: Inferring surface heat flux distributions guided by a global seismic model: particular application to Antarctica, Earth Planet. Sc. Lett., 223, 213-224, 2004.

Van de Berg, W. J., van den Broeke, M. R., and van Meijgaard, E.: Reassessment of the Antarctic surface mass balance using calibrated output of a regional atmospheric climate model, J. Geophys. Res., 111, D11104, doi:10.1029/2005JD006495, 2006.

Van den Broeke, M. R., van de Berg, W. J., and van Meijgaard, E.: Firn depth correction along the Antarctic grounding line, Antarct Sci., 20(5), 513-517, doi:10.1017/S095410200800148X, 2008.

Vaughan, D. G., Corr, H. F. J., Ferraccioli, F., Frearson, N., O’Hare, A., Mach, D., Holt, J., Blankenship, D., Morse, D., and Young, D. A.: New boundary conditions for the West Antarctic ice sheet: subglacial topography beneath Pine Island Glacier, Geophys. Res. Lett., 33, L09501, doi:10.1029/2005GL025588, 2006. 